\title{
Inhibition of Growth and Development of Agaricus bisporus by Polyoxin D
}

\author{
By D. A. WOOD AND J. B. W. HAMMOND \\ Glasshouse Crops Research Institute, Rustington, Littlehampton, Sussex
}

(Received 17 September 1976)

INTRODUCTION

The antibiotic polyoxin D specifically inhibits chitin synthase in fungi (Corbett, 1974). The development of sporophores of the basidiomycete Coprinus cinereus has been shown to require chitin synthase activity (Gooday, I972; Gooday, de Rousset-Hall \& Hunsley, 1976). These authors found that sporophore development of $C$. cinereus was inhibited by concentrations of polyoxin D similar to those which inhibited the activity of chitin synthase preparations in vitro.

The edible mushroom Agaricus bisporus (Lange) Imbach contains chitin in its cell walls (Kreger, I954; Michalenko, Hohl \& Rast, I976). To determine if chitin synthase activity is involved in mycelial growth and fruit body expansion of $A$. bisporus, we have examined the effect of polyoxin $\mathrm{D}$ on these processes. We have also examined the effect of cycloheximide, a protein synthesis inhibitor.

\section{METHODS}

Organism. Agaricus bisporus strains D62 I and D649 were used. These are of direct commercial origin.

Assessment of inhibition of colony growth. Cultures of $A$. bisporus strain D62I were inoculated on to malt agar plates (Wood, 1976). Polyoxin D was incorporated into the plates before inoculation by spreading $0.2 \mathrm{ml}$ of sterile filtered solutions of polyoxin $\mathrm{D}$ on to the surface of the medium. Concentrations are expressed as those present in the agar. After inoculation the plates were incubated at $25^{\circ} \mathrm{C}$ and colony diameters were measured at intervals. Ten replicate plates were measured for each treatment.

Treatment of growing and excised sporophores. Growing sporophores were treated by injecting sterile solutions of polyoxin $\mathrm{D}$ into the stipe base. Approximately $40 \mu \mathrm{l}$ containing $200 \mu \mathrm{g}$ polyoxin D was introduced into the sporophore. Alternatively, sporophores were harvested at about stage 2 of development (Hammond \& Nichols, I976) by cutting across the stipe approximately I $\mathrm{cm}$ below the velum. Measurements were made of the stipe length and cap diameter, using calipers. The sporophores were then placed with the cut stipe ends dipping into small beakers containing $2 \mathrm{ml}$ of solutions of polyoxin $\mathrm{D}$ at 2,20 or $100 \mu \mathrm{g} \mathrm{ml}^{-1}$, cycloheximide at $100 \mu \mathrm{g} \mathrm{ml}^{-1}$ or distilled water. The sporophores and beakers were kept in chambers at $90 \%$ relative humidity for 2 days. During this period all of the solution was imbibed. The sporophores were then removed and the cap and stipe were measured again.

Chitin content. The treated sporophores were separated into cap, lower stipe and upper stipe tissues. Samples of these were homogenized in distilled water. Duplicate samples of the homogenate were removed and dried to constant weight. Other samples of the homogenate were treated with $10 \%(\mathrm{w} / \mathrm{v}) \mathrm{NaOH}$ at $100{ }^{\circ} \mathrm{C}$ for $30 \mathrm{~min}$ and centrifuged at $6000 \mathrm{~g}$ for Io min. The pellets were treated with $2 \%(\mathrm{v} / \mathrm{v}) \mathrm{HCl}$ at $20^{\circ} \mathrm{C}$ for $\mathrm{I} \mathrm{h}$, centrifuged and then 
treated with $10 \%(\mathrm{w} / \mathrm{v}) \mathrm{NaOH}$ for $30 \mathrm{~min}$. Centrifugation was repeated and the pellets were washed twice with distilled water. The final pellets were resuspended in $5 \mathrm{ml} 6 \mathrm{M}-\mathrm{HCl}$ in ampoules. The ampoules were sealed and the samples were hydrolysed for $\mathrm{I} 2 \mathrm{~h}$ at $100{ }^{\circ} \mathrm{C}$. $\mathrm{HCl}$ was then removed by evaporation and the dried material was redissolved in distilled water. Samples of this solution were assayed for glucosamine using the procedure of Ride \& Drysdale (1972). Glucosamine contents were assumed to be directly related to chitin contents.

Chemicals. Polyoxin D was kindly supplied by Dr S. Suzuki, Rikagaku Kenyusho, Japan. Cycloheximide was obtained from Sigma.

\section{RESULTS AND DISCUSSION}

Polyoxin D was inhibitory to mycelial growth of $A$. bisporus. Colony growth was completely inhibited at $\mathrm{I} \mu \mathrm{M}$ and was approximately $50 \%$ inhibited at $0 \cdot \mathrm{I} \mu \mathrm{M}$ but was not visibly affected at $0.01 \mu \mathrm{M}$. The lowest concentration examined that gave complete inhibition (I $\mu \mathrm{M}$ ) corresponded closely to values of $\mathrm{I} \cdot 4$ and $0.6 \mu \mathrm{M}$ respectively obtained for the $K_{1}$ of polyoxin $\mathrm{D}^{\text {"on }}$ chitin synthase preparations from Neurospora crassa (Endo, Kakiki \& Misato, 1970) and Mucor rouxii (Bartnicki-Garcia \& Lippman, 1972). The value of $K$ for chitin synthase from $C$. cinereus with polyoxin D was $3 \mu \mathrm{M}$ (Gooday et al., 1976).

After harvest of the sporophore of $A$. bisporus, the stipe lengthens and the cap expands to expose the developing gills (Hammond \& Nichols, 1975). Treatment with polyoxin D or cycloheximide reduced this expansion (Table I); sporophores treated with antibiotics expanded only some I 2 to $13 \%$ over 2 days. There was less inhibition of growth in the cap tissues; this may be due to incomplete translocation of the inhibitor into the cap tissue.

The sporophores used were of approximately $\mathrm{IO} g$ fresh weight. Thus there was an overall concentration of polyoxin D of $38 \mu \mathrm{M}$ in those sporophores treated with $2 \mathrm{ml}$ of antibiotic solution at $100 \mu \mathrm{g} \mathrm{ml}^{-1}$. Gooday (1972) showed that 10 $\mu \mathrm{M}$-polyoxin D considerably diminished the growth of excised stipes of $C$. cinereus and $190 \mu \mathrm{M}$ was completely inhibitory. Development of sporophores of $A$. bisporus was also partly inhibited by cycloheximide indicating that continuing protein synthesis is required for sporophore enlargement. In longitudinal sections of polyoxin D-treated sporophores, the tissue of the lower stipe and the pileus appeared unchanged, but the upper stipe regions had become very brown and soft (Fig. I). It is known that maximum elongation occurs in the upper stipe region of $A$. bisporus (Bonner, Kane \& Levey, 1956).

Gooday (1972) has suggested that the softening of $C$. cinereus stipes following polyoxin $\mathrm{D}$ treatment may be due to the uncoupling of wall synthesis and degradation thus allowing uncontrolled autolysis to proceed. Coprinus sporophores grow faster than those of $\boldsymbol{A}$. bisporus and, unlike the sporophores of $A$. bisporus, they undergo extensive autolysis at the end of development (Iten \& Matile, 1970). Thus the autolytic system of $A$. bisporus sporophores is probably less active which may account for the observed difference in tissue softening between the two species. Browning and softening of the upper stipe region was much less marked in cycloheximide-treated sporophores. This may be due either to the inhibition of synthesis of autolytic enzymes or to the persistence of chitin synthase activity.

Antibiotic treatment of sporophores attached to underlying mycelium was also inhibitory to their development. When polyoxin D was injected into very small sporophores of approximately Io $\mathrm{mm}$ height, the whole sporophore browned and autolysed. Gill development was also considerably retarded by polyoxin $\mathrm{D}$ treatment and this tissue showed considerable autolysis. Basidiospore formation was inhibited by at least $50 \%$ by the treatments with 20 or $100 \mu \mathrm{g}$ polyoxin $\mathrm{D} \mathrm{ml}^{-1}$.

Analysis of chitin levels showed that sporophores treated with polyoxin D and cyclo- 

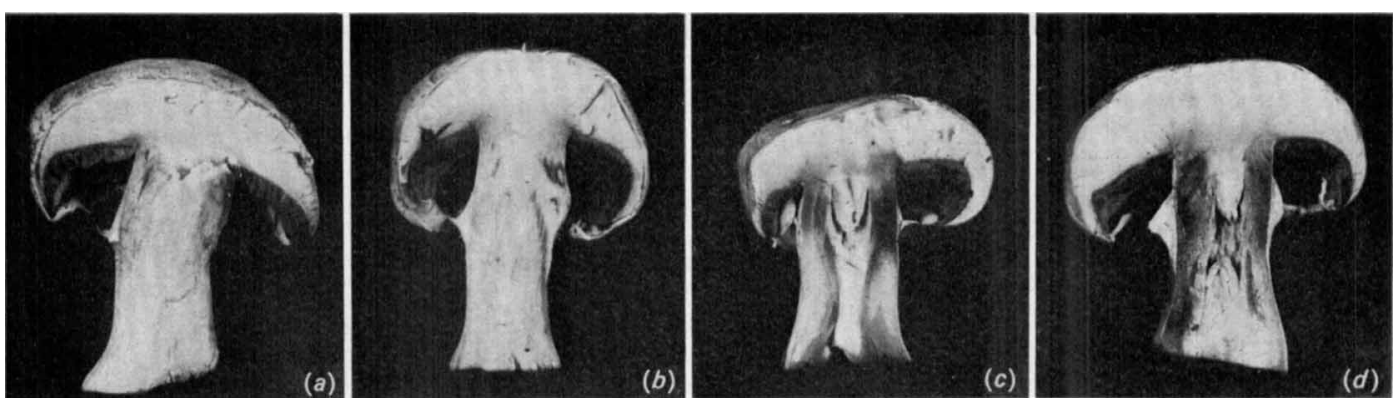

Fig. I. Longitudinal sections of mushrooms treated with polyoxin $\mathrm{D}$ for $48 \mathrm{~h}$ with $(a) \circ,(b) 4,(c) 40$ and $(d) 200 \mu \mathrm{g}$ antibiotic in $2 \mathrm{ml}$ water.

Table I. Percentage increases in stipe length and pileus diameter of sporophores after 2 days treatment with polyoxin $D$ or cycloheximide

Controls were treated with distilled water for 2 days. Data are from three experiments; the means for 10 samples are given \pm the standard error of the mean.

\section{Treatment}

Control

Polyoxin D $\left(100 \mu \mathrm{g} \mathrm{ml}^{-1}\right)$

Cycloheximide (I00 $\mu \mathrm{g} \mathrm{ml}^{-1}$ )

Stipe length
$(\%$ increase)
$25 \pm 3$
$13 \pm 1$
$13 \pm 2$
Pileus diameter $(\%$ increase $)$

$23 \pm 2$

$17 \pm 2$

$18 \pm 2$

Table 2. Chitin content of sporophores after 2 days treatment with polyoxin $D$ or cycloheximide, and of sporophores analysed while fresh

Results are expressed as percentages relative to the chitin content of sporophores treated with distilled water for 2 days. Data are from four experiments; the means for 12 samples are given \pm the standard error of the mean.

\begin{tabular}{lccr}
\multicolumn{1}{c}{ Tissue } & $\begin{array}{c}\text { Polyoxin D } \\
\left(\mathrm{I} 00 \mu \mathrm{g} \mathrm{ml}^{-1}\right)\end{array}$ & $\begin{array}{c}\text { Cycloheximide } \\
\left(\mathrm{I} 00 \mu \mathrm{g} \mathrm{ml}^{-1}\right)\end{array}$ & Fresh \\
Lower stipe & $45 \pm 4$ & $63 \pm 3$ & $6 \mathrm{I} \pm 5$ \\
Upper stipe & $46 \pm 3$ & $67 \pm 4$ & $75 \pm 6$ \\
Cap & $80 \pm 8$ & $\mathrm{I} 3 \pm 5$ & I07 \pm 5
\end{tabular}

heximide had a lower chitin content than untreated sporophores (Table 2). Sporophores harvested at the same time and analysed immediately also had less chitin. Since no carbon source was supplied to the sporophores during the treatment, the net chitin synthesis which occurs during development of excised sporophores must derive from other cellular components. Polyoxin D-treated sporophores had less chitin than fresh sporophores analysed immediately. This may indicate that the antibiotic treatment caused some hydrolysis of chitin. This is consistent with the observation of autolysis in the upper stipe tissue; furthermore, it seems likely that the mechanism for cell wall growth in $A$. bisporus is similar to that in $C$. cinereus (Gooday et al., 1976). Cycloheximide-treated sporophores showed chitin levels similar to those in sporophores analysed while fresh. The results from cycloheximidetreated sporophores also show that protein synthesis is required for net chitin synthesis. It appears, therefore, that the growth of the mycelium and sporophore of $A$. bisporus requires an active chitin synthase, and that the enzyme has a similar affinity for polyoxin $D$ to that of chitin synthase in other fungi. 


\section{REFERENCES}

BARTNICKI-GARCIA, S. \& LIPPMAN, E. (I972). Inhibition of Mucor rouxii by polyoxin D: effects on chitin synthetase and morphological development. Journal of General Microbiology 7r, 30I-309.

BonNer, J. T., KANE, K. K. \& LeVEY, R. H. (1956). Studies on the mechanics of growth in the common mushroom Agaricus campestris. Mycologia 48, 13-19.

Corbetr, J. R. (1974). The Biochemical Mode of Action of Pesticides. London and New York: Academic Press.

Endo, A., KaKIKI, K. \& Misato, T. (1970). Mechanism of action of the antifungal agent polyoxin D. Journal of Bacteriology 104, I89-196.

Gooday, G. W. (1972). The effect of polyoxin D on morphogenesis in Coprinus cinereus. Biochemical Journal 129, I7-18P.

Gooday, G. W., DE Rousset-Hall, A. \& Hunsley, D. (1976). The effect of polyoxin D on chitin synthesis in Coprinus cinereus. Transactions of the British Mycological Society 67, 77-83.

Hammond, J. B. W. \& Nichols, R. (1975). Changes in respiration and soluble carbohydrates during the post-harvest storage of mushroom (Agaricus bisporus). Journal of the Science of Food and Agriculture. 26, 835-842.

Hammond, J. B. W. \& Nichols, R. (1976). Carbohydrate metabolism in Agaricus bisporus (Lange) Sing: changes in soluble carbohydrates during growth of mycelium and sporophore. Journal of General Microbiology 93, 309-320.

Iten, W. \& MATILE, P. (I970). Role of chitinase and other lysosomal enzymes of Coprinus lagopus in the autolysis of fruiting bodies. Journal of General Microbiology 6r, 30 I-309.

KREGER, D. R. (1954). Observations on cell walls of yeasts and other fungi by X-ray diffraction and solubility tests. Biochimica et biophysica acta $\mathbf{1 3}, \mathrm{I}-9$.

Michalenko, G. O., Hohl, H. R. \& Rast, D. (1976). Chemistry and architecture of the mycelial wall of Agaricus bisporus. Journal of General Microbiology 92, 25I-262.

Ride, J. B. \& DRYSDale, R. B. (1972). A rapid method for the chemical estimation of filamentous fungi in plant tissue. Physiological Plant Pathology 2, 7-I 5.

Wood, D. A. (1976). Primordium formation in axenic cultures of Agaricus bisporus (Lange) Sing. Journal of General Microbiology 95, 3I 3-323. 